\title{
XVIII. On the theoretical constitution of the compounds of ammonia
}

\section{Robert Kane M.D. M.R.I.A.}

To cite this article: Robert Kane M.D. M.R.I.A. (1840) XVIII. On the theoretical constitution of the compounds of ammonia , Philosophical Magazine Series 3, 17:108, 120-126, DOI: $10.1080 / 14786444008650125$

To link to this article: http://dx.doi.org/10.1080/14786444008650125

$$
\text { 曲 Published online: } 01 \text { Jun } 2009 .
$$

\section{Submit your article to this journal $₫$}

Џ Article views: 3

Q View related articles $₫$ 


\section{On the Theoretical Constitution of the Compounds of Ammonia. By RoBert Kane, M.D., M.R.I.A.}

T $\mathrm{N}$ the course of the investigations to which $I$ have subjected 1 the various classes of compounds that ammonia is capable of forming, it has been my lot to submit to the consideration of chemists a great number of theoretical views to which I had been led by my experimental results, and by which I conceived that the mutual connexion of the different classes of ammoniacal compounds could be explained, and their origin and properties accounted for more satisfactorily than it was possible to do by means of the ideas that had been previously received in science. In advancing this new theory of the nature of ammonia and its compounds, I was not so sanguine as to expect that cur ideas of a department of chemistry so complex and so important could be immediately or easily modified, or that the adoption of my views could take place without much conflicting reasoning and discussion. In this respect I have had cause to be very much gratified. All principles that can be considered as really vital to my theory have been adopted by the most eminent chemical philosophers, and in place of being dissatisfied that in the collateral parts of the theory some portions have been thought not positively proved, and which have hence been criticized and left for the time aside by Graham and by Rose, I was at once surprised and pleased to see how little had appeared in the eyes of these acute-minded chemists unfit for being at once adopted into science.

I believe, however, that even in those portions of the theory to which Graham and Rose have not acceded, some of the difficulties arise from a want of clearness and detail in the description of my views, into which error I fell from being too anxious to avoid prolixity. As also since that period some additional evidence has been obtained which corroborates my opinions, I shall now advert to those points which are yet debated, and perhaps place them in a clearer point of view than had been done in my former paper. So far as regards the action of ammonia without water, all my ideas have been adopted; but in the relation of the ammonia and water in the common ammoniacal salts, where the ammonium theory of Berzelius comes into question, the evidence for my theory has not appeared so perfect. In fact, in order to see the true relation of the Berzelian theory to mine, it is necessary to contemplate the common salts of ammonia under two different points of view,-1st, their position as alkaline salts, and 2nd, their po- 
sition as compound bodies, roithout reference to any other circumstance. In the first the proper theory of the salts of ammonia is that of Berzelius, but for the second purpose it is necessary to adopt the ideas on which mine is founded.

For in fact the question is, What is sal-ammoniac? Its most striking philosophical character is its equivalence to chloride of potassium. It has the same crystalline form. It enters into combination subject to the same laws. They are two bodies formed decidedly upon the same plan. But chloride of potassium contains only two elements, while sal-ammoniac. contains three. There is one common to both. The residual elements are equivalent, and $\mathrm{Cl} \mathrm{K}$ and $\mathrm{Cl} \mathrm{N} \mathrm{H}_{4}$, as well as $\mathrm{K}$ and $\mathrm{N} \mathrm{H}_{4}$, are bodies which correspond to each other. Ammonium when isolated, as it has, in the amalgam, all but been, appears to possess the properties of an alkaline metal; it markedly resembles potassium. That is the Berzelian theory, in which to the full I believe as well as Berzelius. The equivalency of sal-ammoniac and chloride of potassium is a fact, and the equivalency of the $\mathrm{K}$ in the one and of the $\mathrm{N} \mathrm{H}_{4}$ in the other, is the natural inference from it. When therefore the equivalency of the ammoniacal and potash salts is under question, the ammonium theory is correctly used: it is not ammonia, it is not amidide of hydrogen which replaces potash, but it is to be called oxide of ammonium in comparison.

But if we for a moment cease to consider the relation of the ammoniacal and the potash compounds, and taking sal-ammoniac by itself, proceed to examine what light can be derived from other sources towards illustrating its internal constitution, the question presents itself, can we believe the ammonium to be ready-formed in sal-ammoniac? Can we consider the ammonium, which in the amalgam gives up its hydrogen spontaneously, to retain it so strongly when in contact with iodine or chlorine, and to enter into combination only as a single and perfect group? The answer to this question, in the framing of which all the classes of ammonia compounds require to be taken into account, led me to the development of my theory.

'The combinations of ammonia with the anhydrous chlorides of copper, zinc, and mercury, resemble in all essential characters sal-ammoniac, and moreover, like it, those which are volatile or soluble without decomposition are found to belong to the regular system of crystallization. They further combine with the metallic chlorides of the magnesian class to form double chlorides. Thus there are 
1. $\mathrm{Cl} \mathrm{H}_{4} \mathrm{~N}$ and $\mathrm{Cl} \mathrm{Cu}+\mathrm{Cl} \mathrm{H}_{4} \mathrm{~N}$.

2. $\mathrm{Cl} \mathrm{Cu} \mathrm{N} \mathrm{H}$ and $\mathrm{Cl} \mathrm{Cu}+\mathrm{Cl} \mathrm{Cu} \mathrm{H}_{8} \mathrm{~N}$.

3. $\mathrm{Cl} \mathrm{ZnN} \mathrm{H} \mathrm{NH}_{3}$ and $\mathrm{Cl} \mathrm{Zn}+\mathrm{Cl} \mathrm{Zn} \mathrm{H}_{3} \mathrm{~N}$.

4. $\mathrm{Cl} \mathrm{Hg} \mathrm{N} \mathrm{H}$ and $\mathrm{Cl} \mathrm{Hg}+\mathrm{Cl} \mathrm{Hg} \mathrm{H}_{3} \mathrm{~N}$.

The completeness of the analogy thus indicated is acknowledged by Graham, who proposes to extend the Berzelian theory so as to include these cases. He assumes, that in the compound radical ammonium the hydrogen may be replaced by a metal, and thus a cuprammonium $\mathrm{N} \mathrm{H}_{3} \mathrm{Cu}$, a zincammonium $\mathrm{N} \mathrm{H}_{3} \mathrm{Zn}$, a hydrargammonium $\mathrm{N} \mathrm{H}_{3} \mathrm{Hg}$, may be capable of individual existence. If $\mathrm{Hg}$ and $\mathrm{H}$ are replaceable, then $\mathrm{Hg}_{2} \mathrm{H}_{2} \mathrm{~N}$ is equivalent to $\mathrm{H}_{4} \mathrm{~N}$, and thus he agrees with me that the type of sal-ammoniac and white precipitate ( $\mathrm{Cl} \mathrm{H}$. $\mathrm{H}$ Ad and $\mathrm{Cl} \mathrm{Hg}+\mathrm{Hg}$ Ad on my theory) is the same.

But why have we not $\mathrm{Cl} \mathrm{Hg}_{3} \mathrm{H} \mathrm{N}$, or $\mathrm{Cl} \mathrm{Cu}_{3} \mathrm{H} \mathrm{N}$, or $\mathrm{Cl}$ $\mathrm{Hg}_{4} \mathrm{~N}$ and $\mathrm{Cl} \mathrm{Zn}{ }_{4} \mathrm{~N}$, taking their place among these bodies generated by ammonia? For $\mathrm{Cu}_{4} \mathrm{~N}$ or $\mathrm{Zn}_{4} \mathrm{~N}$ would also be equivalent to ammonium. The replacement stops when there remain yet two equivalents of hydrogen to the nitrogen; and it is only by a temperature such as destroys completely the constitution of these bodies that a metallic azoturet can be produced.

The compounds containing oxygen acids are precisely similar to those chlorides just described. The bodies

$\mathrm{SO}_{3} . \mathrm{O} \mathrm{Cu} \mathrm{N} \mathrm{H}_{3}$ and $\mathrm{S} \mathrm{O}_{3} . \mathrm{OCu}+\mathrm{SO}_{3} . \mathrm{OCuNH}_{3}$

$\mathrm{SO}_{3} . \mathrm{OZnN} \mathrm{H}_{3}$ and $\mathrm{SO}_{3} . \mathrm{OZn}+\mathrm{SO}_{3} . \mathrm{OZnN} \mathrm{H}_{3}$

$\mathrm{SO}_{3}$. OH N H $\mathrm{H}_{3}$ and $\mathrm{SO}_{3} . \mathrm{OH}+\mathrm{SO}_{3}$. O H N H and $\mathrm{SO}_{3} \cdot \mathrm{N} \mathrm{H}_{3}+\mathrm{SO}_{3} \cdot \mathrm{OH} \mathrm{N} \mathrm{H}_{3}$

are so obviously similar in constitution, that the one explanation of their internal structure must be admitted.

There exist thus two sorts of compounds, which are ordinary ammoniacal salts with metallic oxide in place of water, or in the words of the theory of Graham, that contain ammonium in which hydrogen is replaced by a metal ; those as $\mathrm{Cl} . \mathrm{Hg} \mathrm{N} \mathrm{H}$, in which one equivalent, and those as $\mathrm{Cl} . \mathrm{Hg} \mathrm{N} \mathrm{H} \mathrm{Hg}_{2}$, in which two equivalents have been thus replaced. The substitution stopping there shows that $\mathrm{N} \mathrm{H}_{2}$ is fixed, and thus that even if these various sorts of ammonium be admitted, the amidogene must be considered as pre-existing in them; and as

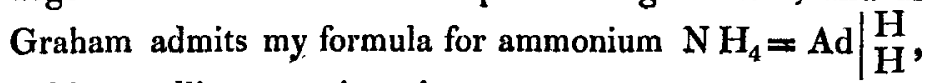
so his metallic ammoniums become

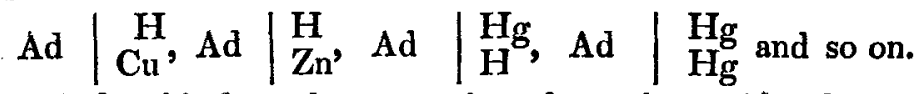

Under this form the ammonium theory is capable of being 
extended so as to embrace a large class of the ammoniacal compounds newly discovered, --but can it embrace all? When calomel is treated by water of ammonia there is formed the body, $\mathrm{Hg}_{2} \mathrm{Cl}+\mathrm{Hg}_{2} \mathrm{~N} \mathrm{H}_{2}$. If the ammonium theory be applied to this body, are we to make a new compound radical, and say it is $\mathrm{Cl}+\mathrm{N} \mathrm{H}_{2} \mathrm{Hg}_{4}$, and to say that the corresponding body $\mathrm{SO}_{3} \cdot \mathrm{Hg}_{2} \mathrm{O}+\mathrm{Hg}_{2}$ Ad is $\mathrm{S} \mathrm{O}_{3} \cdot \mathrm{O} \mathrm{N} \mathrm{H}_{2} \mathrm{Hg}_{4}$ ? Here, then, is no parallel whatever; these bodies lie altogether out of the possibility of replacement connecting them with ordinary ammonium; and it would be far too violent a supposition to assume the existence of a body, $\mathrm{N} \mathrm{H}_{6}$, in order to support the disputed existence of a more likely body, $\mathrm{N} \mathrm{H}_{4} \cdot \mathbf{I}$ consider this example as being fatal to Graham's view. Sublimate $\mathrm{Cl} \mathrm{Hg}$ gives white precipitate $\mathrm{Cl} \mathrm{Hg}$. $\mathrm{Hg} \mathrm{Ad}$, calomel $\mathrm{Cl} \mathrm{Hg}_{2}$ gives black precipitate $\mathrm{Cl} \mathrm{Hg}_{2}$. $\mathrm{Hg}_{2}$ Ad; relations so simple, so natural, that it should require very strong reasons indeed to prove that they are not those consonant to truth.

If the theory of metallic ammoniums were adopted, it would be only just to give to it its proper form. A sulphate of ammonia perfectly isomorphous with sulphate of potash contains $\mathrm{S}_{3} \cdot \mathrm{N} \mathrm{H}_{3}+2 \mathrm{H} \mathrm{O}$. The replacing element of the potassium is therefore $\left(\mathrm{N} \mathrm{H}_{5} \mathrm{O}\right)$; there is no doubt of this; it is one of Mitscherlich's best-established determinations; $\left(\mathrm{N} \mathrm{H}_{4}\right)$ and $\left(\mathrm{N} \mathrm{H}_{5} \mathrm{O}\right)$ are equally isomorphous with potassium. Hence as sublimate treated in the cold with ammonia gives $\mathrm{Cl} \mathrm{N} \mathrm{H}_{4}$ and $\mathrm{Cl}$. $\mathrm{N} \mathrm{H}_{2} \mathrm{Hg}_{2}$, so in boiling water we get $\mathrm{CI}+\left(\mathrm{N} \mathrm{H}_{2} \mathrm{Hg}_{4} \mathrm{O}_{2}\right)$ equally equivalent, and a sort of complex ammonium. The ammonia turbeth is thus: $\mathrm{S} \mathrm{O}_{3}+\mathrm{O}\left(\mathrm{N} \mathrm{H}_{2} \mathrm{Hg}_{4} \mathrm{O}_{2}\right)$; there is $\mathrm{NO}_{5}+\mathrm{O}\left(\mathrm{N} \mathrm{H}_{2} \mathrm{Hg}_{4} \mathrm{O}_{2}\right)$ and $\mathrm{I}\left(\mathrm{N} \mathrm{H}_{2} \mathrm{Hg}_{4} \mathrm{O}_{2}\right)$, and so on. Now the correspondence of the common oxychloride of mercury to these bodies has been proved by Ullgren, and it should therefore be looked upon as a chloride of a compound radical $\mathrm{Cl}+\left(\mathrm{Hg}_{4} \mathrm{O}_{3}\right)$. This is truly the principle involved in Graham's idea of compound ammoniums ; for no matter where we begin, we find the chain by which the common salts of ammonia and the common basic salts are connected so perfect, that whatever principle we apply to one includes the others. Already, two years ago (May, 1838, Annalen der Pharmacie), I started the question, Were basic salts salts of compound radicals? and Liebig, in adapting a theory to the salts of platina discovered by Gros, approached nearly to the embodying of the same idea; but further examination showed me that it is one which is at present quite unfit for science, the even partial adoption of which would throw into confusion the most positive and simplest systematic arrangements that chemistry possesses, and hence do much harm and no good. Having so 
far considered the degree of weight which should be attached to the extension of the ammonium theory proposed by Graham, I shall now pass to the objections which have appeared to Ruse to lie against some portions of my theory.

Admitting the consistency and completeness of the arrangement which the compounds of ammonia with the dry oxygen acids and with the hydrogen acids assume according to my views, the illustrious analyst of Berlin yet considers that the assimilation of the hydrated ammonia salts of oxygen acids to those salts of the same acids which contain two equivalents of base is forced and unnatural; and he says that in place of attending to the great fact of the isomorphism of ammonium and potassium, I have neglected and suppressed that fact. This I by no means did; but this isomorphism was not the only thing to be taken into account. In fact, when all things were considered, the argument about the isomorphism of the two alkalies is of most force on the other side, and my opinion is that on the side of ammonia we have outflanked, as it were, the line of metallic bases, and that the constitution of ammonium, subamidide of hydrogen, is that which we shall hereafter find the alkaline metals to possess. The masterly researches of Rose himself on the sulphates and carbonates of ammonia are, as I believe, remarkably in favour of my view. In the carbonates of ammonia $\mathrm{C} \mathrm{O}_{2} \cdot \mathrm{NH}_{3}+\mathrm{CO}_{2} . \mathrm{NH}_{3} . \mathrm{HO}$ and $\mathrm{C} \mathrm{O}_{2} \mathrm{HO}+\mathrm{C} \mathrm{O}_{2}$. $\mathrm{HO} . \mathrm{NH}_{3}$ what complete evidence do we obtain of the identity of type of $\mathrm{N} \mathrm{H}_{3}=\mathrm{Ad} \mathrm{H}$ and $\mathrm{H} \mathrm{O}$ ? In like manner if we look upon the series

$$
\begin{aligned}
& \mathrm{SO}_{3} \cdot \mathrm{AdH}+\mathrm{SO}_{3} \mathrm{HO} \text {. Ad } \mathrm{H}, \\
& \mathrm{SO}_{3} \cdot \mathrm{OH}+\mathrm{SO}_{3} \mathrm{HO} \text {. Ad } \mathrm{H}, \\
& \mathrm{SO}_{3} \cdot \mathrm{O} \mathrm{Cu}+\mathrm{SO}_{3} \mathrm{HO} \text {. Ad } \mathrm{H}, \\
& \mathrm{S} \mathrm{O}_{3} \cdot \mathrm{O} \mathrm{Cu}+\mathrm{SO}_{3} \mathrm{CuO} \text {. Ad H, }
\end{aligned}
$$

we are driven, in order to avoid considering the recognised ammonium salt as a salt with two equivalents of base, to the adoption of the views of metallic ammoniums already sufficiently refuted.

On my theory the only hypothetic assumption is the existence of amidogen. The subsequent principles adopted that

1. Ammonia $\mathrm{N} \mathrm{H}_{3}$ is $-\mathrm{N}_{2} \cdot \mathrm{H}=\mathrm{Ad}+\mathrm{H}$,

2. Sal-ammoniac Cl $\mathrm{H} . \mathrm{N} \mathrm{H}_{3}$ is $\mathrm{Cl} \mathrm{H}+\mathrm{H}$ Ad,

3. White precipitate $\mathrm{Cl} \mathrm{Hg}_{2} \mathrm{~N} \mathrm{H}_{2}$ is $\mathrm{Cl} \mathrm{Hg}+\mathrm{Hg} \mathrm{Ad}$,

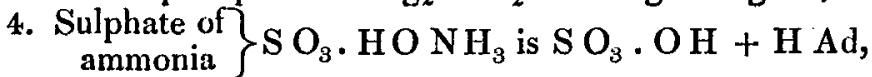

5. The black substance $\mathrm{Cl} \mathrm{Hg}_{4} \mathrm{~N} \mathrm{H}_{2}$ is $\mathrm{Cl} \mathrm{Hg}_{2}+\mathrm{Hg}_{2} \mathrm{Ad}$,

6. Ammonium if ever isolated $\mathrm{N} \mathrm{H}_{4}$ is $\mathrm{H}_{2} \mathrm{Ad}$,

are all experimental and necessary results; there is nothing 
hypothetical about them; everything follows from experiment.

Now the existence of amidogene is one of the best-established and most universally received hypotheses in chemistry; moreover, it is adopted also by Graham and by Rose. But how many more hypotheses must they adopt for the theory of ammonium! I shall only count up a very few, or better, state that the number of hypothetical bodies necessary for the complete ammonium theory would be equal to the number of possible metallic amidides, therefore equal to the number of metallic chlorides and oxides at present known; and this without at all touching on the theory of basic salts, which, as I have shown, is a necessary consequence of the theory of complex ammoniums.

If general and simple laws can be obtained by the introduction of an hypothesis, and according as experimental research proceeds, the new facts gained are found to regulate themselves according to it, a real and important service is conferred upon science by him to whom we are indebted for it. But when a theory must change its shape and make a new assumption for each new fact discovered, as soon as the direct tendency of the theory is at an angle with that of research, and it must tack from side to side to keep the course of discovery in its line, its day has passed; and notwithstanding the services rendered to chemical theory by the hypothesis of ammonium, it is now, as I conceive, incapable of retaining its old position. Its great utility was in fixing attention on the relations of the ammoniacal and potash salts; but for explaining the immensely extended classes of compounds which ammonia is now known to form, it is insufficient.

In a paper lately published by Mitscherlich, he describes a compound of chloride and azoturet of mercury $2 \mathrm{HgCl}+\mathrm{N} \mathrm{Hg}_{3}$, and he makes an observation which, as connected with the present subject, I shall here notice. He says that the equivalent of white precipitate is not $\mathrm{Cl} \mathrm{Hg}+\mathrm{Hg}$ Ad, but three times that, because it requires $3\left(\mathrm{Cl} \mathrm{Hg}+\mathrm{HgAd}\right.$ ) to give $\mathrm{Cl} \mathrm{Hg}+2 \mathrm{NH}_{3}$ and $2 \mathrm{Cl} \mathrm{Hg}+\mathrm{N} \mathrm{Hg}_{3}$ : he says that also amide of potassium $\mathrm{K} \mathrm{N} \mathrm{H}$ should be taken $3 \mathrm{KAd}$, because it gives $2 \mathrm{~N} \mathrm{H}_{3}$ and $K_{3} N$. Now this appears to me to be a very irrational method, for then the body $\mathrm{Cl} \mathrm{Hg} \mathrm{N} \mathrm{H}$, the simple formula of which Mitcherlitch admits, should be $8\left(\mathrm{Cl} \mathrm{Hg} \mathrm{NH}_{3}\right)$, because it gives $2 \mathrm{Cl} \mathrm{Hg}+3 \mathrm{Cl} \mathrm{Hg} g_{2}+\mathrm{N}+4 \mathrm{~N} \mathrm{H}_{3}+3 \mathrm{Cl} \mathrm{NH}_{4}$. The hydrate of phosphorous acid should be $4 . \mathrm{PO}_{3}+3 \mathrm{HO}$, because it gives $\mathrm{P} \mathrm{H}_{3}$ and $3 \mathrm{PO}_{5}$; and a crowd of other examples might be brought forward. The equivalent formula of a body cannot be fixed thus from a single action or property. 
The formula of sulphate of ammonia is not $4\left(\mathrm{~S} \mathrm{O}_{3} . \mathrm{N} \mathrm{H}_{4} \mathrm{O}\right)$, because by heat it gives $2\left(\mathrm{SO}_{2} \cdot \mathrm{N} \mathrm{H}_{4} \mathrm{O}\right)+2 \mathrm{SO}_{2}+2 \mathrm{~N}$, but every property must be taken into account, and our idea of the body derived from a careful induction, based on a study of all the facts known of it and of its congeners.

The red substance described by Mitscherlich resembles, in fact, those obtained by Rose with sublimate and phosphuretted hydrogen, and the bodies I have myself described, containing arsenic. In fact, as Laurent and Bineau have noticed for azote, and I myself for arsenic and phosphorus, these substances replace oxygen or amidogene in the proportion of onethird of their ordinary equivalent. Phosphuretted hydrogen $\mathrm{PH}_{3}$ does not resemble ammonia $\mathrm{N} \mathrm{H}_{3}=\operatorname{Ad~} \mathrm{H}$, but $\frac{\mathrm{P}}{3}$. $\mathrm{H}$ resembles Ad $\mathrm{H}$ or $\mathrm{HO}$. The compound of iodide and phosphuret of hydrogen resembles not the hydriodate of ammonia, which is $\mathbf{I}+\mathbf{H} A d$, but the oxy-chloride of mercury, and the compound of chloride and phosphuret of mercury is similar. There are thus

$$
\left.\begin{array}{l}
\mathrm{HI}+3 \mathrm{H} \frac{\mathrm{P}}{3} \\
\mathrm{Hg} \mathrm{Cl}+3 \mathrm{Hg} \frac{\mathbf{p}}{3} \\
\mathrm{Hg} \mathrm{Cl}+3 \mathrm{Hg} \mathrm{O}
\end{array}\right\} \text { all corresponding bodies. }
$$

Now the ammonia compounds when decomposed by heat pass into this class, in one or two cases the action being sufficiently violent spontaneously to effect it, and the substance of Mitscherlich is

$$
2 \mathrm{Hg} \mathrm{Cl}+3 \mathrm{Hg} \frac{\mathrm{N}}{3} \text { resembling the above. }
$$

I discovered this body myself when analysing white precipitate; but as I did not wish to stray from the direct discussion of the amidides, 1 did not publish anything about it at the time. I formed also some others of the same class, which, as soon as I can obtain leisure I will complete the examination of, and give the details of their history.

XIX. On the Composition of Inulin. By Mr. E. A. PARIELL* THIS substance, which was first discovered by V. Rose 1 in the root of Inula Helenium, in 1804, has since been found by Payen and other chemists in several other roots, as

* Communicated by Professor Graham. 